\title{
The Professionalism, Competence, Organizational Commitment \& Job Satisfaction on The Performance of Auditor
}

\author{
Elvira Luthan ${ }^{1}$, Syahril Ali, Ety Hairaty ${ }^{2}$ \\ ${ }^{1}$ Fakultas Ekonomi dan Bisnis, Universitas Andalas, Padang, Indonesia \\ ${ }^{2}$ Fakultas Ekonomi dan Bisnis, Universitas Andalas, Padang, Indonesia
}

\begin{abstract}
This study aimed to examine the effect of professionalism, competence, organizational commitment and job satisfaction on the performance of auditors at the public accounting firm (KAP) in Padang (6 Firms) and Medan (18 Firms) obtained by 96 respondens. This study was also conducted to determine if there are differences them. This research using primary data and sampling is done by purposive sampling method. The reasons for selecting different objects based on their differences in location and working environment on each KAP could cause differences mindset and worldview, values that are believed or how auditors work and indirectly led to differences in the understanding of how to generate performance the good one. The results of the analysis are the professionalism, competence and organizational commitment affect the performance of auditors, but job satisfaction has no influence on the performance of auditors. There is no difference among auditors in Padang and Medan because wherever auditor work then work will have the same standard, as set out in the professional ethics of auditors.
\end{abstract}

Keyword. auditor performance; competence; job satisfaction; organizational commitment; professionalism.

Article history. Received August, 2019. Revised October, 2019.Accepted December, 2019

Corresponding author. Email. viraluthan@gmail.com

How to cite article. Luthan, E., Ali, S., Hairaty, E., Ekonomi, F., \& Andalas, U. (2019). The Professionalism, Competence, Organizational Commitment \& Job Satisfaction on The Performance of Auditor. The International Journal of Business Review (The Jobs Review), 2(2), 89-106. https://doi.org/https://doi.org/10.17509/tjr.v2i2.21345

\section{INTRODUCTION}

Business dynamics that shot so quickly and passes the boundary between countries as well as the implementation of the ASEAN Economic Community (AEC) at the end of 2015, inevitably requires all segments of the profession to have the quality and high competitiveness. With the existence of this MEA, then wide open opportunity that is opening of wider labor market for professional and competent labor. The accountant is one of the professions recognized equality, preparing for the tough competition especially with the enactment of MEA. Therefore, accountants in Indonesia must improve their quality to be able to host their own country. To be able to compete an accountant is required to improve the professionalism, quality, competence and performance.

The development of a public accounting profession in a country is also in line with the development of the company. Public accounting firm also has a strategic position as a third party within the client company. One of them to audit the company's financial statements so that public accountants are required to improve its performance in order to produce a reliable audit products. A public accountant is a profession of public trust. Auditor professionalism has been set out in the Standards of Professional Public Accountants (SPAP) which provide guidance in providing audit services that bind the auditor to comply with the provisions of the profession in carrying out its work from beginning to end. 
The role of professionalism can be explained more broadly i.e. in terms of its influence on other elements in the public accountant. Professionalism becomes an element of motivation that contributes to performance (Hampton and Hampton, 2004). The results of Kalbers and Fogarty (1995), Siahaan (2010) and Agustia (2011) stated that professionalism has a positive effect on the performance of public accountants. That is, if professionalism increases then the performance will also increase, so we can assess the professionalism of the public accountant through its performance.

In SPAP also stated that auditors should have the knowledge, skills, and other competencies needed to perform its responsibilities. Lee and Stone (1995), defines competence as considerable expertise which can explicitly be used to perform an audit objective. Tubbs (1992) and Brown, et al (2007) stated that the higher the auditor's experience and knowledge will make the auditor increasingly sensitive to errors in the presentation of the financial statements and the impact on performance is getting better. When the auditor has a good competence, then the understanding of a financial report will also be better.

The advanced organization requires the willingness and seriousness of the employees to strive to achieve the goals for the sake of the organization's interests and sustainability. The high commitment of an auditor will encourage the creation of performance enhancement and its involvement in the organization it shelves so that it will provide benefits for the survival of the organization. Organizational commitment is seen as the strength of the relationship between the identification of a person individually and his involvement in a particular organization (Mowday et al., 1979). Research conducted by Somers and Birnbaum, (1998), shows that organizational commitment has a positive effect on auditor performance. Yet another research conducted by Hanna and Firnanti (2013) and Prajitno (2012) stated that organizational commitment has no effect on auditor performance.

One other factor in an individual who has an important influence in one's performance is job satisfaction. The nature of job satisfaction is a feeling of pleasure or dislike that is relatively different from objective thinking and behavioral desires (Davis and Newstrom, 2004). Job satisfaction shows one's effective response to work. Increased job satisfaction for auditors associated with the fulfillment of work expectations in conducting the examination. An auditor who has a high level of job satisfaction will support his performance well too. Job satisfaction variables in Sutton's (1993) and Gautama and Arfan (2010) studies also show that a person who gets the peak of job satisfaction will positively affect the work itself and potentially improve performance.

Auditor performance can be measured by four dimensions of personality that is with ability, professional commitment, motivation, and job satisfaction. According Trisnaningsih (2004), success and performance of a person, much determined by the level of competence, professionalism, as well as commitment to the field he is engaged. Auditor performance can also be seen based on the results and audit process that is done in accordance with existing standards and rules (Larkin, 1990).

Previous research on the influence of auditor professionalism, auditor competence, organizational commitment, and job satisfaction on the performance of auditors has been 
largely done because it is an interesting topic to study. However, in many similar studies, in addition to the inconsistency of the results of previous research, there has been no research that chose the object of research on auditors who work at Public Accounting Firm in Padang and Medan. In addition, the challenges of the accounting profession in the future with the coming into force of the ASEAN Economic Community (AEC) era inevitably demand all segments of the profession, especially the services of accounting profession, to have high quality and competitiveness, so as to be able to compete in regional and international level. Similar previous studies have been conducted, but there is no research that examines auditors working in KAP Padang and Medan. This research is constituted by the different locations, cultures and working environments in KAP that could give effect to the difference in mindsets, behavior and understanding of the values that are believed to be about how to make a good performance. Good or bad performance of an auditor cannot be separated from the attitude and behavioral aspects of the auditor itself. This concept of behavior is related to the elements of motivation, perception, attitudes and personality that are highly relevant to accounting (Siegel and Marconi, 1989).

Devotion to the profession is reflected in the dedication of professionalism by using the knowledge and skills possessed. Work is defined as a goal, not just as a means to an end (Hall in Astriyani, 2007). This totality has become a personal commitment, so the main compensation that is expected of the work is spiritual satisfaction, and then the material. Professional behavior according to Arens et al. (2013), are: responsibility, public interest, integrity, objectivity and independence, the appropriateness and scope and nature of services. Cahyasumirat (2006) states that dedication to the profession and social obligations has a positive relationship to the performance of auditors. Social obligation is a view of the importance of the role of the profession as well as the benefits gained by both society and fellow professionals because of the work (Hall 1998 in Astriyani, 2007). Auditor awareness for the continuity of the profession and services provided so that professional accountants assume responsibility to clients, communities, colleagues and in themselves will foster moral attitude to do the best possible job.

Kurniawan (2009) states that independence as a view of a professional person must be able to make their own decisions without pressure from other parties (government, clients, those who are not members of the profession). Existence of intervention from outside is considered as an obstacle that can interfere with professional autonomy. A sense of independence will arise through the freedom gained. Strictly structured and controlled work by management, it is difficult to create tasks that create a sense of independence in the task. Independence is already embodied in the auditor will be realized also in the determination of materiality levels, so that truly reflect the real situation.

Confidence in the profession is a belief that the most authoritative to assess professional work is a fellow profession, not an outsider who has no competence in the field of science and the work of the auditor (Hall in Astriyani, 2007). If the assessing work has the same knowledge, then the error will be known. The existence of belief in the profession provides motivation for auditors to provide results of work and consideration that can be accounted for. 
Other research conducted by Rahmawati (1997) and Cahyasumirat (2006) also states that belief in the profession affects the performance of auditors. Relationships with fellow professions are the use of professional ties as a reference, including formal organizations and informal colleagues as the main ideas in work (Hall in Astriyani, 2007). Through these professional ties, professionals build professional awareness. With so many additional inputs will add to the accumulation of auditor's knowledge so that it can be wise to make the planning and consideration in the auditing process. The study also states that relationships with fellow professions affect the performance of auditors.

Based on the description above, it can be prepared the following research hypothesis: $\mathrm{H}_{1}$ :Auditor Professionalism positively affects the auditor's performance

The influence of competence on auditor performance and competence differences among auditors.

Competence is the qualification required by an auditor to properly perform the audit, which has knowledge in understanding the object being audited, the ability to analyze problems and work together in teams (Ayuningtyaset.al., 2012). Tubbs (1992) states that the higher the experience and knowledge of the auditor makes the auditor more sensitive to mistakes in the presentation of financial statements and the impact on improving performance. By having competence or expertise in professional services, it will affect the report of examination result which is one of the assessment on auditor performance.

The longer period of work and experience that the auditor has, the higher the auditor's competence, the more audit quality will be generated and the auditor's performance improves. The results of the research Effendi (2007) and Awaluddin (2013) showed that work experience had a positive effect on the quality of the results of the examination. This shows that more and more work experience of an auditor then increasing the quality of the examination results. These factors are supported by the personal quality of a good auditor.

\section{$\mathrm{H}_{2}$ : Competence affects the performance of the auditor.}

The influence of organizational commitment to the performance of auditors

The success and performance of a person in a field of work is determined by the professionalism. Professionalism must be supported by a commitment to achieve the highest levels. Robbins (2007) defines organizational commitment as a state in which a person agrees with the organization as well as its goals and intentions to maintain its membership within the organization. The existence of a commitment can be a boost for a person to work better so that his performance will also increase. Results of research by Ketchand and Strawser, 2001; Fernando et al., (2005) in Marganingsih and Martani (2009) gives the same conclusion that organizational commitment has a positive effect on performance. The results of this study were supported by Trisnaningsih (2007), Marganingsih \& Dwi martini (2009) and Wibowo (2009) which concluded that organizational commitment positively influences auditor performance.

The right commitment will provide high motivation and give a positive impact on the performance of a job. If the auditor feels his soul is tied to the values of the existing organization, then he will feel happy in working, so that his performance can increase. This 
means that the higher the auditor's commitment to an organization, the auditor's performance will be better. Based on the description can be formulated the following research hypothesis.

\section{H3: Organizational commitment affects the performance of the auditor.}

\section{Influence of Job Satisfaction on Auditor Performance}

Greggson (1992) said that job satisfaction is an early sign of an organizational commitment. With commitment at least can affect performance, whether it is directly or indirectly. If an auditor has a maximum job satisfaction, would produce an audit report accurate and reliable, and therefore contributes to the improved performance of the auditors.

Handoko (2002) stated that job satisfaction is an emotional condition both in a happy and unpleasant situation that employees feel in assessing their work. It is visible from a good feedback from an employee about his work and all of the conditions in the working environment. Research Sutton (1993) also explained, someone who gets the peak of job satisfaction will have a positive effect on the work itself and potentially improve performance. The results of this study are supported by Gautama S \& Muhammad (2010), and Nugroho, et al. (2008) that job satisfaction produces a significant positive influence toward performance. Based on the thoughts and results of previous research can be made the fourth hypothesis that is:

\section{H4: Job satisfaction affects the performance of the auditor.}

In addition, the authors also want to test whether there are differences in professionalism, competence, organizational commitment and job satisfaction between auditors at KAP Padang and auditors at KAP Medan. This difference is possible, due to regional and cultural differences and the work environment of the auditors in each KAP. This is expected to have an impact on these variables. Therefore, the authors put it in different test hypotheses to the following two samples:

H5: There is a difference in professionalism between auditors working in Padang City Public Accountant Firm and Medan City Public Accountant Firm

H6: There is a difference in competence between auditors working in Padang City Public Accountant Firm and Medan City Public Accountant Firm

H7: There is a difference in organizational commitment between auditors working in Padang City Public Accounting Firm and Medan City Public Accounting Firm.

H8: There is a difference in job satisfaction between auditors working in the Padang City Public Accounting Firm and the Medan Public Accounting Firm.

\section{METHOD}

This research is an explanatory empirical verification. This research is quantitatively designed with a causal relationship between two or more variables, so the purpose of this study is to see how the influence of one variable on other variables. The main data of this study are primary data, obtained from questionnaires distributed on the specified samples. The method of data analysis in this study with Structural Equation Model (SEM) using Smarts PLS software version 3.0.m3 to see the effect of various endogenous variables with 
auditor performance as exogenous variable. Statistical Package for Social Sciences (SPSS) version 16 to see if there are differences in auditor behavior variables studied on each object.

The population in this study are all auditor on Public Accounting Firm (KAP) in the city of Padang and Medan, who joined the Indonesian Institute of Certified Public Accountants Indonesian (IAPI) in 2016. According to the IAI directory there are seven public accounting firms in Padang and 21 in Medan. The technique of determining the sample using purposive sampling, with criteria, auditors who have working experience of at least two years and have done the audit assignment. This criterion was chosen because generally auditors with minimum 2 year's experience in KAP have been given responsibility for conducting audit (Willet and Page, 1996; Pierce and Sweeney, 2004). He has had the opportunity and experience to adapt and assess his working conditions. Finally the obtained sample is 98 respondents.

The professionalism variables in this study use the instruments developed by Arens \& Loebbecke (2013), namely responsibility, public interest, integrity, objectivity \& independence, equality, the scope of nature and services. Competence variables are measured using instruments from Agung Rai (2010) that are personal qualities, special skills, and general knowledge. Organizational commitment, using instruments developed by Meyer and Allen (1990) are the affective commitment, continuance commitment, and normative commitment. Meanwhile, job satisfaction variable using the instrument from Fred Luthan (1989) is the response to the situation, the acquisition of results and attitudes.

This research uses data analysis method with Structural Equation Model, Smarts' PLS version 3.0 support, to analyze the effect of X variables on Y. Statistical Package for Social Sciences (SPSS) version 16 to see if there are differences of auditor behavior variable examined on each object. Data analysis with PLS is done by evaluating measurement model / outer model and structural model (inner model). The samples tested in this study consisted of two independent groups, so as to know whether or not there was a difference of perception among the sample groups, an Independent Sample t-test was used with the help of the SPSS program.

\section{RESULTS AND DISCUSSION}

The object of this study is the auditor who works in Public Accounting Firm in Padang and Medan. For the city of Padang there are 7 public accounting firms but only 6 offices grant permission for this study. As for the city of Medan, there are 21 public accounting firms and are willing to carry out this research is 18 offices. The number of questionnaires distributed for each public accounting firm in Padang ranged from 3 to 8 questionnaires, adjusted to the request of each office. While for Medan the number of questionnaires distributed per each office ranged from 2-6 questionnaires. The total number of questions contained in the questionnaire was 40 . Of the 100 questionnaires distributed, which were used for the analysis were 96 questionnaires.

The Outer Model or Measurement Model is used to test the validity of the construct and the reliability of the instrument. The construct validity test in the measurement model (outer model) with the reflective indicator can be measured by loading scores and using the Average Variance Extracted (AVE) parameter, Communality. A construct is declared variable if the value of loading score $>0.7$, AVE $>0,5$ and Communality $>0,5$. For outer model testing, after eliminating the indicators that have a loading factor of $<0.5$ deleted, then 
obtained the result that all items have a valid statement that is loading factor>0.5, AVE> 0,5 and Communality> 0,5 (see figure 1 ).

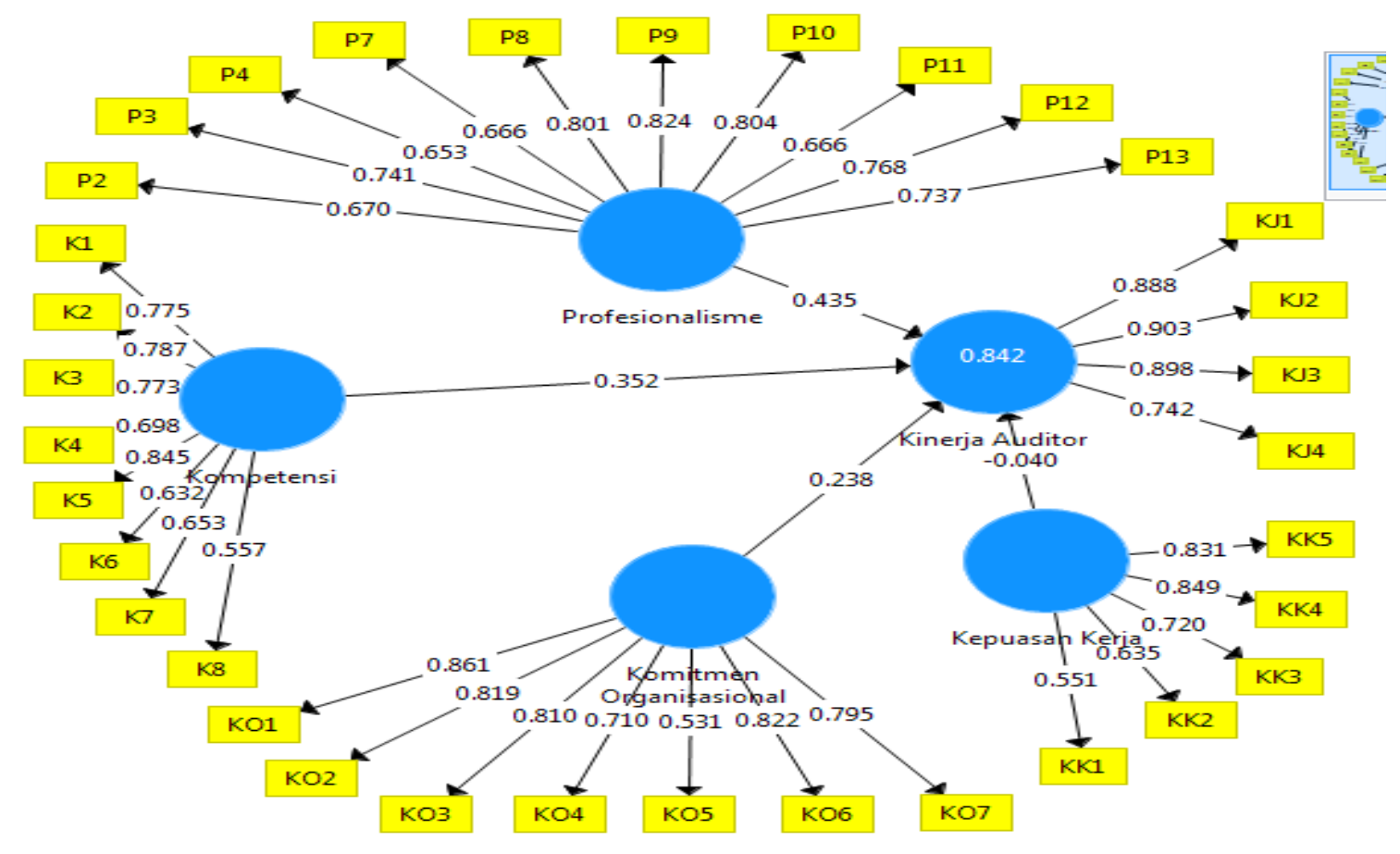

Figure 1. Final Outer Model

The construct reliability of the measurement model with reflexive indicator can be measured by the composite reliability and Cronbach's alpha value of the indicator block measuring the construct. A construct is said to be reliable if the value of composite reliability is above 0.70 (Abdillah and Jogiyanto, 2015). The value of the composite reliability of this study indicates that the value for all constructs is above 0.7 . This indicates that all constructs in the estimated model meet the criteria reliably. The lowest composite reliability value is 0.845 on job satisfaction, while the highest value of composite reliability is 0.921 in professional variables. The structural model (inner model) is assessed by R-square for each latent variable. The R-square value shows the level of variation of the independent variables changes to the dependent variable. R-square of this research is 0,842 , indicating that $84,2 \%$ variable of auditor's performance can be influenced by 4 independent variable that is professionalism, competence, organizational commitment and job satisfaction.

\section{Hypothesis Testing Results}

Statistical test with PLS for each hypothesis is done by using simulation. For this purpose, a bootstrap method is performed on the sample data. Bootstrap test is also intended to minimize the problem of research data is not normal. The following table shows the results of bootstrap and path coefficients.

Table 1. Path Coefficients Inner Model 
ELVIRA LUTHAN ${ }^{I}$, SYAHRIL ALI \& ETY HAIRATY'/The Professionalism, Competence, Organizational Commitment \& Job Satisfaction on The Performance of Auditor

\begin{tabular}{lcccc}
\hline & Original Sample $(\mathrm{O})$ & Sample Mean $(\mathrm{M})$ & Standar Deviasi & $\begin{array}{c}\text { T-Statistic }(\mathrm{O} \\
\text { / STEER })\end{array}$ \\
\hline $\mathrm{P} \rightarrow \mathrm{KJ}$ & 0,435 & 0,430 & 0,092 & 4,724 \\
$\mathrm{~K} \rightarrow \mathrm{KJ}$ & 0,352 & 0,351 & 0,094 & 3,729 \\
$\mathrm{KO} \rightarrow \mathrm{KJ}$ & 0,238 & 0,235 & 0,081 & 2,946 \\
$\mathrm{KK} \rightarrow \mathrm{KJ}$ & $-0,040$ & $-0,026$ & 0,066 & 0,595 \\
\hline
\end{tabular}

Path coefficient is used to test the hypothesis that is comparing the t-table and t-statistic. If the t-statistic value is higher than the t-table value, then the hypothesis is accepted. For a 95\% confidence level (alpha 5\%) then the t-table value for the one-tailed hypothesis is $\geq$ 1.64. In the table can be seen that the first, second and third hypothesis accepted because of t-statistic above t-table is above 1.64. This means that, professionalism, competence, and organizational commitment have a positive effect on auditor performance. As for the fourth hypothesis, t-statistic smaller than t-table or smaller than 1.64 , which means job satisfaction does not affect the performance of auditors.

The original sample values in the table represent the most dominant variables that affect the auditor's performance. Professionalism ranks the top and most dominant influence on auditor performance that is equal to 0.435 . While job satisfaction becomes the behavioral variable that has the minimal influence on auditor's performance that is equal to $-0,040$.

\section{Discussion}

The increasing need for professional services of the public accountant as an independent party, also requires the public accountant profession to improve its performance in order to produce a reliable audit product for the needy. Hasil pengujian hipotesis pertama menunjukkan bahwa profesionalisme mempengaruhi kinerja auditor. This study supports previous research conducted by Siahaan (2010), Agustia (2011), Nugraha \& Ramantha (2015), and Arumsari (2014) which concluded that professionalism positively and significantly influences the auditor's performance. That is, if professionalism increases then the performance will also increase, so we can assess the professionalism of the auditor through its performance. Therefore professional auditors will be better at generating the audit results, thereby impacting on improving auditor performance. This will certainly increase the trust of those who need professional services. It can be concluded that auditors who have the views and attitudes of good professionalism will contribute that can be trusted by decision makers. However, the results of this study contradict the research conducted by Fuad Haris (2015), which states that professionalism has no effect on the performance of auditors. This is due to the lack of confidence in the importance of the work of an auditor and the lack of contact with colleagues so that profession less builds professional awareness.

Auditor competence is defined as someone who has extensive procedural knowledge and skills that is shown in the audit experience. In conducting the audit, the auditor should act as an expert in accounting and auditing. Achievement of skills begins with formal education, then through audit experience and practice. In addition, the auditor must undergo technical training. The auditor must have the competence in conducting the audit in order to produce a good quality audit. An auditor who has the competence or expertise in his professional services will affect the results of the audit report, which is one of the assessments of the auditor's performance. Results of the second hypothesis test show that 
competence has an influence on the performance of auditors. These results support the research of Christiawan (2002), Awaluddin. (2013) and Efendy (2010) which concluded that competence positively and significantly influences the performance of public accountant. The higher the competency level of an auditor then the performance will also increase. Auditors who have high competence will be able to audit objectively, carefully and thoroughly. Highly educated auditors will have a broad knowledge of their field and be able to keep up with the more complex developments, and with their expertise to know the problems more deeply so that the auditor will be able to produce a good quality audit or in other words the performance will be better. However, these results contrast with research Ariesanti (2001), which states that competence does not affect the audit performance.

Organizational commitment is an encouragement to an individual to do something to support the success of organizational goals and prioritize the interests of the organization. A person committed to the organization will demonstrate the relationship between employees and the organization as demonstrated by a strong desire to maintain organizational membership, accept organizational values and goals and be willing to do its job for the achievement of organizational goals and survival. The result of the third hypothesis test shows that organizational commitment has a significant effect on auditor performance. This research is consistent with research conducted by Ketchand and Strawser (2001), Wibowo (2009), Trisnaningsih (2007), and Marganingsih \& Marhani (2009) which stated that organizational commitment has a positive effect on auditor performance. This indicates that high auditor commitment will lead to improved performance and involvement of auditors in the organization, in this case, the auditor firm (KAP). This will benefit the survival of the auditor firm and encourage its performance as an auditor. This organizational commitment also reflects the dedication and loyalty of auditors in carrying out their duties and obligations to support the success of the Auditor Firm. So it can be concluded that a high organizational commitment to the auditor will have an impact on performance improvement, which will improve the survival of the Auditor Firm. However, research conducted by Wilopo (2006), Prajitno (2012), and Hanna \& Firmanti (2013) gave different results. Their results conclude that organizational commitment has no effect on the performance of an auditor. Based on the results of their research, the auditors in working only maintain the attitude of professionalism and have the only motivation to perform certain tasks in order to achieve a goal. For them, organizations are not entirely and not part of themselves. So that organizational commitment does not affect the performance of auditors.

Job satisfaction is a general attitude toward a person's job that shows the difference between the number of awards earned by the worker and the amount they believe they should receive. The term job satisfaction refers to the general attitude of an individual to his work. A person with a high level of job satisfaction shows a positive attitude towards the work while a person who is not satisfied with his work showed a negative attitude towards the job (Robbins, 2003: 312). Job satisfaction is an individual thing, each individual has a different level of satisfaction. Job satisfaction is an effectiveness or an emotional response to various aspects of work means that job satisfaction is not a single concept, otherwise a person can be relatively satisfied with an aspect of his job but not satisfied with one or several other aspects.

97 | The International Journal of Business Review (The Jobs Review) Vol.2 | No.2 | 2019 
The results of the fourth hypothesis test show that job satisfaction does not affect the performance of auditors. This result is inconsistent with research that has been done by Gautama \& Arfan (2010) and Futri (2014). Their results state that an auditor who has a high level of job satisfaction will show its performance well because the nature of job satisfaction is a feeling of pleasure or dislike that is relatively different from objective thinking and behavioral desires. This pleasure or displeasure arises because when employees work they bring with them the desires, needs, and experiences of the past that shape their work expectations. Thus it can be said that the higher the level of work expectations can be met, the higher the job satisfaction felt auditors. If job satisfaction can be fulfilled, of course, the auditor will be able to provide good performance in carrying out its work. This study shows different results from several previous studies. Hypothesis testing results obtained that job satisfaction perceived auditors have no effect on performance. This can be due to the level of job satisfaction is relative and different for each individual. For some auditors, the goal of working in KAP is to improve science and practice field so that they are willing to do a stressful job with complex tasks. Because for them the most important is how to complete the work according to the target and time. So job satisfaction has no effect on auditor performance.

Table 2. Result of Test Hypothesis

\begin{tabular}{|c|c|c|}
\hline No & Hypothesis & Result \\
\hline 1 & $\begin{array}{l}\mathrm{H}_{1} \text { : Auditor Professionalism positively affects the auditor's } \\
\text { performance }\end{array}$ & Accepted \\
\hline 2 & $\mathrm{H}_{2}:$ Competence affects the performance of the auditor & Accepted \\
\hline 3 & $\begin{array}{l}\mathrm{H}_{3} \text { : Organizational commitment affects the performance of } \\
\text { the auditor }\end{array}$ & Accepted \\
\hline 4 & $\mathrm{H}_{4}$ : Job satisfaction affects the performance of the auditor & Not Accepted \\
\hline
\end{tabular}

\section{Different Test Results (Independent Sample t-test)}

To examine the differences of the research variables based on the sample group of auditors working at Auditor Firm (KAP) in Padang and Medan conducted by using independent sample t-test with SPSS program (see table 3 below).

Auditors who have high professionalism will contribute reliably to decision makers. From the result of the different test, independent t-test, it is known that there is no difference of professionalism between auditors working in KAP Padang and KAP Medan. This indicates that the auditor is required to be professional and obey all forms of standards specified in the Standards of Professional Public Accountants (SPAP). SPAP provides guidance on providing audit services and binds the auditor to comply with the provisions of the profession in carrying out its work from beginning to end without discriminating where the auditor works.

Table 3. Result of Different Test

\begin{tabular}{llr}
\hline No & \multicolumn{1}{c}{ Hypothesis } & Results \\
\hline 1 & $\mathrm{H}_{5}:$ There is a difference in professionalism between auditors working in & Rejected \\
& Padang City Public Accountant Firm and Medan City Public Accountant & \\
& & \\
& Firm. & \\
& $\mathrm{H}_{6}:$ There is a difference in competence between auditors working in \\
& Padang City Public Accountant Firm and Medan City Public Accountant & \\
& Firm.
\end{tabular}

98 | The International Journal of Business Review (The Jobs Review) Vol.2 | No.2 | 2019 


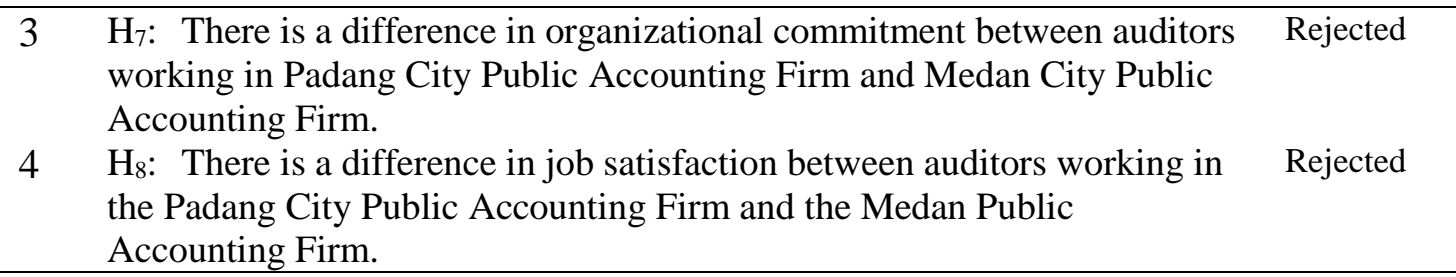

The auditor should be sufficiently knowledgeable to be able to understand the criteria used and sufficiently capable or competent to know exactly the type and amount of evidence required. This means that a higher level of auditor's understanding of the field will improve the quality of the audit it performs. From the results of statistical calculations, it is known that there is no difference in competence between auditors working in KAP Padang and KAP Medan. This indicates that the auditors in each KAP already have the required level of competence that complies with the standards.

Organizational commitment reflects the dedication and loyalty of an auditor in carrying out its duties and obligations to support the success of the institution where it works. Organizational commitment is a form of commitment that can support the achievement of organizational goals. High organizational commitment in the auditor will make the performance also better so that will improve the survival of the Public Accounting Firm, where the auditor shelter. A committed auditor may be a truly stable and productive auditor. Thus, organizational commitment will affect one's motivation in working. From the result of the different test, independent t-test known that there is no difference of organizational commitment between auditors working in KAP Padang and Medan. This indicates that the auditors in each KAP have the same values and goals as the auditor's job. The auditor is involved in achieving the goals of the organization and intends to maintain its membership in the organization. All hope that becomes motivation will be achieved if the auditor has shown a loyal attitude and works fully for his organization regardless of where the auditor is working.

The meaning of work for one substantially in accordance with the purpose that drives a person to meet their needs. Positively, work can generate income, life experience, and respect for others, achieve a sense of independence and achievement needs, as well as a means to connect with other people. Job satisfaction is defined as the feelings of employees about the fun or not of their work, which is the result of the perception of experience during his tenure. An auditor is required to show high performance in order to produce a quality audit. Good performance can be influenced by good job satisfaction. If the auditor is satisfied with his work, the resulting performance will also be good. Conversely, if the auditor is not satisfied with the circumstances of his work, its performance can be bad. Based on data processing, the result of homogeneity test of variance from both groups of the sample for organizational commitment variable obtained conclusion, that there is no difference of job satisfaction between auditors working in KAP Padang and Medan. This is because an auditor who does not have the satisfaction of his work will still be required to comply and submit to the provisions of the profession in carrying out his work, from beginning to end without distinguishing the place and environment of the auditor's work. 


\section{CONCLUSION}

Conclusion (1) Auditor professionalism positively affects the auditor's performance. A high professional attitude will support the auditor's performance better. (2) Auditor competence has a positive effect on auditor performance. A high auditor independence attitude will result in better auditor performance. (3) Organizational commitment has a positive effect on auditor performance. This organizational commitment reflects the dedication and loyalty of an auditor in carrying out its duties and obligations in relation to supporting the success of the institution in which he works. (4) Job satisfaction has no effect on auditor performance. These findings indicate that job satisfaction does not affect an auditor's performance. (5) There is no difference in professionalism, competence, organizational commitment and job satisfaction between auditors working in KAP Padang and KAP Medan. That is, every auditor in carrying out his profession is required to have an attitude of professionalism, level of competence, commitment to a high organization that will support the results of good performance. For that effort to improve the performance of an auditor can be started by improving the attitude of professionalism, level of competence, commitment to the organization of each auditor. Furthermore, the absence of this difference is also based on the dimensions of behavior that deviate from the rules established by the accounting standards and the existing auditing professions and standards will raise the risks of lawsuits that may be faced as a result of different understandings and worldviews do the audit assignment.

Limitations (1) This study used survey method through a questionnaire so that the conclusion has taken only based on the data collected through the use of instruments in writing. The disadvantages of the survey approach generally lie in internal validity. The survey approach used has limitations, such as the determination of the selected measures or the respondents' own answers without the intervention of their superiors and the lack of control over who responds to the questionnaire. (2) The use of Likert scale also has weaknesses, as the same score is considered to have the same or identical characteristics. (3) Most of the sample of this research are auditors working on KAP located in Padang and Medan City only. The complexity of task and competition burden faced by auditors in each KAP in different regions may be different, so the results of this study may not be generalizable to auditors working in KAP across Indonesia. (4) The characteristics of individual auditor behavior investigated in this study are limited to only a few aspects of behavior, namely professionalism, competence, organizational commitment and job satisfaction alone. Thus there may be other individual behavior variables that may also have an effect on the performance of an auditor.

Research suggestion (1) Practically, the results of this study can be used as input for KAP leaders in evaluating policies to create a work environment that can support an auditor's performance improvement. The policy covers various fields such as the determination of audit time budget, evaluation system on auditor personnel performance, new auditor recruitment, professional development program, and socialization of professional goals and values. (2) The results of this study confirm the results of previous research and contribute to the auditor in an effort to improve performance and performance. Auditors are expected to further improve their professional behavior in every audit process, constantly striving to increase the weight of self-competence in order to produce audited financial statements more qualified and able to be more loyal and committed to the organization. Increased auditor performance is absolutely necessary, given the professional services of accountants more rapidly needed in the community. (3) The results of this study can be used as the basis for further research by adding some other aspects of behavior that affect the performance of auditors. 


\section{REFERENCES}

Abdillah, Willy dan Jogiyanto. 2015. Partial Least Square (PLS) Alternatif Structural Equation Modeling (SEM) dalam Penelitian Bisnis. Ed.1. Yogyakarta: ANDI.

Agoes, Sukrisno. Auditing (Pemeriksaan Akuntansi) oleh Kantor Akuntan Publik. Jilid 2, Lembaga Penerbit Fakultas Ekonomi UI, 2008

Agung Rai, I Gusti. 2010. Audit Kinerja pada Sektor Publik. Jakarta: Grafindo.

Agustia, Dian. 2006. Pengaruh Profesionalisme Auditor terhadap Variabel - Variabel Individual Work Outcomes. Majalah Ekonomi, tahun XVI, No. 1 April 2006.

2011. The Influence of Auditor's Professionalism to Turnover Intentions an

Empirical Study on Accounting Firm in Java and Bali. Journal of Economics and

Engineering. ISSN: 2078-0346. Vol 2, No 1. February. Surabaya.

Aranya, N, and K. Ferris (1984), "A Re-Examination of Accountants OrganizationalProfessional Conflict." The Accounting Review (January): 1-15.

Arens dan Loebbecke. 2008. Auditing pendekatan Terpadu. Edisi Indonesia. Jakarta: Salemba Empat.

Arens, A.A., Elder, R.J., Beasley, M.S. (2013). Auditing dan Pelayanan Verifikasi: Pendekatan Terpadu, alih bahasa oleh Tim Dejakarta, edisi ke 9, Jakarta: Indeks.

Ariesanti, (2001), Persepsi Auditor Terhadap Kualitas Audit. (Tesis), Universitas Gadjah Mada, Yogyakarta.

Arikunto, Suharsimi. 2013. Prosedur Penelitian: Suatu Pendekatan Praktik. Jakarta: Rineka Cipta.

Arumsari, Adelia Lukyta. 2014. Pengaruh Profesionalisme Auditor, Independensi Auditor, Etika Profesi, Budaya Organisasi, Dan Gaya Kepemimpinan Terhadap Kinerja Auditor (Studi Pada Kantor Akuntan Publik di Bali). Universitas Udayana, Denpasar.

Awaluddin, Murtiadi. 2013. Pengaruh Independensi dan Kompetensi Auditor Terhadap Kepuasan Kerja dan Kinerja Auditor Inspektorat Kota Makassar. ASSET Volume 3 Nomor 2.

Baotham, Sumintorn. 2007. Effects of Professionalism on Audit Quality and Self-image of CPAs in Thailand. International Journal of Business Strategy Publisher: International Academy of Business andEconomic. ISSN: 1553-9563

Batubara, R.I. (2008). Analisis Pengaruh Latar Belakang, Pendidikan Profesional, Pendidikan Berkelanjutan dan Independensi Pemeriksa terhadap Kualitas Hasil Pemeriksaan (Studi Empiris pada Bawako Medan). Universitas Sumatera Utara. Medan.

Bedard, Jean dan, Michelene Chi T.H. 1993. Expertise in Auditing. Journal of accounting practice \& theory 12: 21-45.

Boynton, William C., Johnson, Raymond N., Kell, Walter G. Modern Auditing, Erlangga, Jakarta, 2007.

Cahyani, Nur. 2007. Analisis Pengaruh Profesionalisme Pemeriksa Pajak, Kepuasan Kerja dan Komitmen Organisasi terhadap Kinerja Karyawan pada Kantor Pajak di Wilayah Semarang). Fakultas Ekonomi Universitas Diponegoro

Cahyasumirat, Gunawan. 2006. Pengaruh Profesionalisme dan Komitmen Organisasi Terhadap Kinerja Internal Auditor, Dengan Kepuasan Kerja Sebagai Variabel Intervening. Fakultas Ekonomi Universitas Diponegoro.

Cherrington, D. J. 1995. The management of Human Resources ( $4^{\text {th }}$ Edition). New Jersey: Prentice Hall Inc. 
Chin, W.W.1998.The Partial Least Square Approach to Structural Equation Modeling. Modern methods for business research, 295 (2), 295 - 336.

Christiawan, Yulius Jogi. 2002. Kompetensi dan Independensi Akuntan Publik, Refleksi Hasil Penelitian Empiris. Jurnal Akuntansi dan Keuangan Vol. 4 No. 2.

David, K dan Newstrom, J. W. 2004. Perilaku dalam Organisasi, Edisi 7 Bahasa Indonesia, Jilid I. Jakarta: Erlangga.

Devisia, Selly, dan Yuskar. 2011. Pengaruh Independensi Auditor, Komitmen Organisasi, Pemahaman Good Governance, Integritas Auditor, Budaya Organisasi, dan Etos Kerja Terhadap Kinerja Auditor (Studi Empiris pada Kantor Akuntan Publik Big Four yang Berafiliasi di Indonesia Tahun 2011. Simposium Nasional Akuntansi XVI Aceh 2011. Juli, Hlm. 1-21.

Direktori Institut Akuntan Publik Indonesia. 2012. Daftar Kantor Akuntan Publik: http:www.iapi.or.id

Efendy, Muh. Taufiq. 2010. Pengaruh Kompetensi, Independensi, dan Motivasi Terhadap Kualitas Audit Aparat Inspektorat dalam Pengawasan Keuangan Daerah (Studi Empiris pada Pemerintah Kota Gorontalo). Fakultas Ekonomi Universitas Diponegoro.

Fernando, J., Mulki, J.P., \& Marshall, G.W., 2005. A Meta-Analysis of the Relationship between Organizational Commitment and Salesperson Job Performance. Journal of Business Research, (58): p. 705 - 714

Ferris dan Aranya. 1983. Komitmen Organisasi. Cetakan ke-3. Jakarta: Ghalia Indonesia.

Fishbein, M. and Ajzen, I., 1975. Belief, Attitude, Intentions and Behavior : An Introduction to Theory and Research. Addison-Wesely Boston, MA.

Futri, Putu Septiani. 2014. Pengaruh Independensi, Profesionalisme, Tingkat Pendidikan, Etika Profesi, Pengalaman dan Kepuasan Kerja Auditor terhadap Kinerja Pada Kantor Akuntan Publik di Bali. Jurnal Akuntansi 8.1: 41-58. ISSN 2302-8556.

Gautama, Ibnu dan Arfan, Muhammad. 2010. Pengaruh Kepuasan Kerja, Profesionalisme, dan Penerapan Teknologi Informasi Terhadap Kinerja Auditor: Studi Pada Kantor BPK RI Perwakilan Provinsi Aceh. Jurnal Telaah \& Riset Akuntansi. 3(2): h:195205.

Ghozali, Imam. 2009. Aplikasi Analisis Multivariate Dengan Program SPSS. Badan Penerbit Universitas Diponegoro. Semarang.

Ghozali, Imam dan Hengky L. 2012. Partial Least Squares: Konsep, Teknik dan Aplikasi menggunakan Program SmartPLS 2.0 M3. Semarang: Badan Penerbit Universitas Diponegoro.

Ghozali, Imam. 2014. Structural Equation Modeling Metode Alternatif dengan Partial Least Squares (PLS). Semarang: Badan Penerbit Universitas Diponegoro.

Gibson, James. L., Ivancevich, John M. dan Donnely, James H., Jr. 1993. Organisasi: Perilaku, Struktur dan Proses. Terjemahan. Jilid 1. Edisi 5. Penerbit: Erlangga, Jakarta.

Gregson.T. 1992. An Investigation of the causal orderimg of job satisfaction and organizational commitment in turnover models in accounting. Behavior Research In Accounting.

Hackett, R.D., Bycio, and P.A. Hausdorf, 1994, Further Assessments of Meyer and Allens. 1991. Three component model Organizational Commitment. Journal of Applied Psychology, Vol. 79, No.4, February, pp.15-23.

Hair, Joseph F, G. Tomas M. Hult, Christian M. Ringle, Marko Sarstedt. 2013. A Primer on Partial Least Squares Structural Equation Modeling (PLS-SEM). SAGE Publications. 
Hall, Ricard H. 1968. Profesionalization and bureaucratation. American Sociological Review Vol 33 No 1 hal 92-104

Hampton, Gerald M. and Hampton, Dorothee L. 2004. Relationship of Professionalism Rewards, Market Orientation and Job Satisfaction among Medical Professionals The Case of Certified Nurse-Midwives. Journal of Business Research Vol. 57.

Handoko, T. Hani, 2002. Manajemen Personalia dan Sumber Daya Manusia. Yogyakarta: BPFE

Hanna, Elizabeth dan Firnanti, Friska. 2013. Faktor-faktor Yang Mempengaruhi Kinerja Auditor. Jurnal Bisnis Dan Akuntansi, Juni, Vol. 15, No. 1, hlm 13-28.

Haris, Fuad. 2015. Pengaruh Pengalaman, Otonomi, Profesionalisme, Ambiguitas Peran, dan Motivasi Terhadap Kinerja Auditor. Universitas Muhammadiyah Surakarta.

Hopwood, A.G. 1976. Accounting and Human Behaviour. Prentice-Hall.

Ikatan Akuntan Publik Indonesia. 2011. Standar Profesional Akuntan Publik. Jakarta: Salemba Empat.

Ikatan Akuntan Indonesia. www.iaiglobal.or.id (diakses tanggal 25 Februari 2016).

Ikhlas Andi, 2014. Independensi Auditor dan Komitmen Organisasi Sebagai Mediasi Pengaruh Good Governance,Gaya Kepemimpinan dan Budaya Organisasi Terhadap Kinerja Auditor.

Ikhsan Lubis, Arfan. 2010. Akuntansi Keperilakuan. Jakarta : Salemba Empat. Edisi 2.

Jensen, M. C and Meckling, W.H. 1976. Theory of the Firm : Managerial Behavior, Agency Costs and Ownership Structure. Journal of Financial Economics, Oktober, 1976, V. 3, No. 4, pp. 305-360.

Jex, Steve M. 2002. Psychology a Scientist Practitioner Approach. Jhon Wiley and Sons, Inc: New York.

Judge, Timothy and Klinger, Ryan. 2007. Job Satisfaction: Subjective Well-Being at Work. In M. Eid \& R. Larsen (Eds.), The Science of subjective well-being (pp. 393-413). New York: Guilford Publication.

Kalbers, Lawrence P. and Fogarty, Timothy J. Professionalism and its Consequences: a Study of Internal Auditors. Auditing Journal of Practice and Theory (Vol. 14 No. 1, 1995).

Ketchand, A.A. dan Strawser, J.R., 2001. Multiple Dimensions of Organizational Commitment: Implications for Future Accounting Research. Behavioral Research in Accounting, Vol. 13: p. $221-251$.

Khikmah, Siti Noor. Pengaruh Profesionalisme terhadap Keinginan Berpindah dengan Komitmen Organisasi dan Kepuasan Kerja sebagai Variabel Intervening. Universitas Diponegoro, 2005.

Kreitner, Robert, dan Kinicki, Angelo. 2005. Perilaku Organisasi (Organizational Behavior). Buku 1 edisi 5. Jakarta: Salemba Empat.

Kuncoro, Mudrajad. 2003. Metode Riset untuk Bisnis dan Ekonomi. Jakarta : Erlangga.

Larkin, Joseph M. 1990. Does Gender Affect Internal Auditor's Performance? The Women CPA. Spring: 20-24.

Lee, Tom and Mary Stone. Competence and Independence: The Congenial Twins of Auditing? Journal of Business Finance and Accounting. 1995.

Lekatompessy, Jantje E. Hubungan Profesionalisme dengan Konsekuensinya: Komitmen Organisasional, Kepuasan Kerja, Prestasi kerja dan Keinginan Berpindah (Studi Empiris di Lingkungan Akuntan Publik)". Jurnal Bisnis dan Akuntansi, Vol. 5 No. 1, April, 2003.

Locke, E.A. 1976. What Is Job Satisfaction? Journal of Organization Behavior and Human Performance, 4. pg. 309 - 336. 
Luthans, Fred. 2006. Perilaku Organisasi, (Alih Bahasa V.A Yuwono, dkk). Edisi Bahasa Indonesia. Yogyakarta: ANDI.

Mangkunegara, Anwar Prabu. 2002. Manajemen Sumber Daya Manusia Perusahaan. Bandung: PT. Remaja Rosda Karya.

Marganingsih, Arywarti dan Dwi Martani (2009). Analisis Variabel Anteseden Perilaku Auditor Internal dan Konsekuensinya Terhadap Kinerja: Studi Empiris pada Auditor di Lingkungan Aparat Pengawasan Intern Pemerintah-Lembaga Pemerintah Non Departemen. SNA XII Palembang.

Maryani, Dwi dan Supomo, Bambang. (2001). Studi Empiris Pengaruh Kepuasan Kerja terhadap Kinerja Individual. Jurnal bisnis dan akuntansi, Vol. 3, No.1, 367-376.

McNeese-Smith, Donna, 1996, Increasing Employee Productivity, Job Satisfaction and Organizational Commitment, Hospital \& Health Services Administration, Vol.41.

Meyer, John P., Allen, Natalie J. and Smith, Catherina A. 1993. Commitment to Organizational and Occupation: Extension and Test of a Three Component Conceptualization. Journal Applied Psychology, Vol. 78. No.4.

Mowday, Richard T., Steers, Richard M. and Porter, Lyman W. 1979. .The Measurement of Organizational Commitment. Journal of Vocational Behavior, Vol. 14, pg 224247 ,

Mulyadi, 2002. Auditing. Edisi VI, buku 1, cetakan keenam, Salemba Empat, Jakarta.

Mulyadi dan Kanaka, Puradiredja. 1998. Auditing. Edisi ke-5. Jakarta. Salemba Empat

Nizarul, Alim. Hapsari, Trisni dan Purwanti, Liliek. 2006. Pengaruh Kompetensi dan Independensi Terhadap Kualitas Audit dan Etika Audit Sebagai Moderasi. Simposium Nasional Akuntansi X, 26-28 Juli 2007, Makassar.

Nugraha, Ida Bagus Satwika dan Ramantha, I Wayan. (2015). Pengaruh Profesionalisme, Etika Profesi dan Pelatihan Auditor terhadap Kinerja Auditor pada Kantor Akuntan Publik di Bali. ISSN: 2301-1018

Prajitno, Sugiarto. 2012. Faktor-Faktor Yang Mempengaruhi Kinerja Akuntan Publik di Jakarta. Jurnal Bisnis Dan Akuntansi. Desember Vol. 14, No. 3, hal. 181-192.

Robbins, P. Stephen. 2003. Organization Behaviour : Concept, Controversies, Aplications. Seventh Edition. Prentice Hall Inc.

Robbins, Stephen. P, \& Judge. 2007. Perilaku Organisasi. Jakarta: SalembaEmpat.

Sapariyah Rina Ani. 2008. Pengaruh Good Governance dan Independensi Auditor Terhadap Kinerja Auditor dan Komitmen Organisasi (Survey Pada Kantor Akuntan Publik di Jakarta). Jurnal Auditing Volume 3 Nomor 2. Universitas Gunadarma, Jakarta.

Sekaran, Uma. 2000. Research Methods for Business. 4th Edition. New York: John-Willey $\&$ Sons Inc.

Siahaan, Victor D. 2010. Pengaruh Profesionalisme Terhadap Komitmen Organisasi Dalam Upaya Meningkatkan Kinerja Auditor (Studi Pada Kantor Perwakilan BPKRI Provinsi Aceh. Jurnal Telaah \& Riset Akuntansi. Vol. 3, No.1, Januari 2010, Hal 10-28.

Siegel, Garry \& H. R. Marconi. 1989. Behavioral Accounting. Cincinnati, Ohio: SouthWestern Publishing Co.

Sherriton J and Stren, J.L. 1997. Corporate Culture: Removing the Hidden Barriers to Team Success, New York: Amacon.

Somers, M.J. and Birnbaum, Dee. 1998. Work-Related Commitment and Job Performance: It's Also The Nature of The Performance That Counts. Journal of Organizational Behavior, (19): 621-634.

Sugiyono. 2008. Statistika untuk Penelitian. Bandung: Alfabeta. 
Sutton, S.G. 1993. Towards an Understanding on The Factors of affecting The Quality of The Audit Process. Decision Sciences.

Sutrisno. 2006. Pengaruh Budaya Organisasi Terhadap Motivasi Kerja, Komitmen Dan Kinerja Organisasi. Jurnal Bisnis dan Akuntansi, Vol. 2, No. 3, Desember 2000.

Triandis, H.C. 1971. Attitudes and Attitudes Change. Jhon Waley and Sons, Inc, New York. Trisnaningsih, Sri. 2004. Perbedaan Kinerja Auditor Dilihat Dari Segi Gender. Jurnal Riset Akuntansi Indonesia. Vol.7. No.1: 108-123. (2007). Independensi Auditor Dan Komitmen Organisasi Sebagai Mediasi Pengaruh Pemahaman Good Governance, Gaya Kepemimpinan Dan Budaya Organisasi Terhadap Kinerja Auditor. SNA X Makassar.

Trotter, R.. J., 1986, The Mystery of Mastery. Psychology Today.

Tubbs, R.M. 1992. The Effects of Experience on The Auditors Organization and Amount of Knowledge. The Accounting Review, (October): vol. 67. No. 4: 783-801.

Vroom, Victor H. 1964. Work and Motivation. New York : John Wiley \& Son, Inc.

Wahyudi, Hendro dan Mardiyah, Aida Ainul. 2006. Pengaruh Profesionalisme Auditor Terhadap Tingkat Materialitas dalam Pemeriksaan Laporan Keuangan. Padang: Simposium Nasional Akuntansi IX.

Wibowo, Hian Ayu Oceani. 2009. Pengaruh Independensi Auditor, Komitmen Organisasi, Gaya Kepemimpinan, dan Pemahaman Good Governance terhadap Kinerja Auditor (Studi Empiris pada Kantor Akuntan Publik di Daerah Istimewa Yogyakarta). Fakultas Ekonomi Universitas Islam Indonesia.

Widodo, Joko. 2008. Membangun Birokrasi Berbasis Kinerja. Malang: Bayu Media.

Wilopo. 2006. Faktor-faktor yang Berpengaruh terhadap Perilaku Disfungsional Auditor: Studi pada Kantor Akuntan Publik di Jawa Timur. Jurnal Akuntansi dan Teknologi Informasi, Volume 5 No. 2. Hal 141-152. Surabaya: STIE Perbanas Surabaya.

Zakki, Muhammad Anis. 2015. Analisa Pengaruh Kompetensi terhadap Kinerja Karyawan pada BMT Tamzis Area Yogyakarta. Universitas Islam Negeri Sunan Kalijaga. Yogyakarta. 